\title{
MORPHOMETRIC AND MOLECULAR GENETIC DIFFERENTIATION OF Apis mellifera caucasica L. HONEY BEE LINES REARED IN SOCHI REGION
}

\section{M.S. FORNARA ${ }^{1}$, A.S. KRAMARENKO ${ }^{1,}{ }^{2}$, S.V. SVISTUNOV 3 , E.M. LYUBIMOV ${ }^{3}$, S.S. SOKOL'SKII ${ }^{3}$, N.A. ZINOVIEVA ${ }^{1}$}

${ }^{1}$ L.K. Ernst All-Russian Research Institute of Animal Husbandry, Federal Agency of Scientific Organizations, pos. Dubrovitsy, Podolsk Region, Moscow Province, 142132 Russia, e-mail n_zinovieva@mail.ru;

${ }_{2}^{2}$ Mykolayiv State Agrarian University, vul. Paris Commune, 9, Mykolayiv, 54020 Ukraine, e-mail kssnail@mail.ru; ${ }^{3}$ Krasnopolyanskii Experimental Station of Beekeeping, Federal Agency of Scientific Organizations, 4, ul. Pchelovodov, pos. Moldovka, Sochi-A, 354393 Russia, e-mail svistunov@list.ru

Acknowledgements:

The equipment of Bioresources and Bioengineering Center of L.K. Ernst All-Russian Research Institute of Animal Husbandry was used.

Supported by the Russian Science Foundation, project 14-36-00039

Received August 14, 2015

\section{Abstract}

Creating specialized lines is one of the techniques of genetic improvement and conservation of breeds and populations of the honeybee. The aim of this study was a comparative assessment of the diversity and differentiation degree of $A$. $m$. caucasica lines based on morphometric analysis and microsatellites (MS). Material for this study was the worker bees of Gray Mountain Caucasian breed (lines $\mathrm{I}-\mathrm{V}, n=728$ ) which were selected in five apiaries in the Greater Sochi of Krasnodar krai. Morphometric analysis included such measurements as the length of the proboscis (LP, $\mathrm{mm}$ ), width of third tergite (W3T, mm) and cubital index (CI). Molecular genetic studies were based on seven MS loci (A024, A88, A113, AP043, HB-C16-05, HB-THE-03, HB-C16-01). The level of variation between families for morphometric parameters was determined by two-way hierarchical analysis of variance. Genetic differences between families for MS were estimated by paired comparison of $F_{\text {st }}$ values. $F_{\text {st }}$ matrix was used for PCA-analysis. To determine the quantitative estimation of variation between families within lines we calculated $F_{s t}, R_{s t}$ (AMOVA). The degree of line's differentiation for morphometric characters was evaluated by calculating the Euclidean distances. The obtained values were used to construct a dendrogram of similarity by a single bond (single linkage) of the hierarchical clustering algorithm. The differentiation of lines for MS was based on calculating the values of Nei genetic distances. Similarity dendrogram was constructed using the method of UPGMA. We performed summary statistic using the software STATISTICA, GenAlEx (v. 6.5.1), PAST (v. 3.03). Morphometric analysis showed the presence of significant differences between the lines for LP and W3T whereas there was no difference between the lines for CI. The greater heterogeneity concerning studied traits in the lines II and $\mathrm{V}$ was revealed, and on the contrary, there was more consolidation in the lines III and IV. Bees of line I differed significantly from the rest of the lines on both traits, but they were characterized by significant differences between families in LP. Analysis of MS profiles showed similar trends in assessing the level of intra- and interfamily variability. We observed an excess of heterozygotes in the line $\mathrm{I}\left(\mathrm{F}_{\text {is }}=-0.048\right)$, which can be considered as an indication of the high heterogeneity. Bees of this line were characterized by a minimal individual $\left(F_{i t}=0.052\right)$ and the maximal interfamily variability $\left(F_{s t}=0,124\right)$. Lines II-V were characterized by a deficiency of heterozygotes $\left(F_{\text {is }}=0.062-0.128\right)$, a relatively higher individual variability $\left(F_{i t}=0.143\right.$ $0.189)$ and lower values of interfamily variability comparing to line $I\left(F_{s t}=0.095-0.104\right)$. The lowest interfamily differences were observed in the lines III and IV $\left(\mathrm{F}_{\mathrm{st}}=0.096\right.$ and 0.095 , respectively). Analysis of the differentiation of the studied lines for morphometric characteristics and MS revealed differences in the structure of the family tree. The dendrogram based on MS data is a reflection of the geographical origin of these lines. The structure of the family tree, based on morphometric characters, does not reflect the geographic closeness (differences) of origin or similarities (differences) in the economically useful traits of studied lines. Thus, the results of our studies of the morphometric parameters and MS show similar trends in assessing intra- and interline variation, but there are differences in assessing differentiation of lines using two methods. In the future complex approach will allow to identify not only breeds of bees with high accuracy, but also smaller taxonomic units. It is hoped that the research results in general can be used in breeding work to restore the purity of the honeybee breeds.

Keywords: honeybee, Apis mellifera caucasica L., DNA marker, morphometry, microsatel- 
Saving diversity of the honeybee (Apis mellifera L., 1758) breeds, as well as of smaller taxonomic units (ecotypes and lines) requires deep fundamental population genetic investigations of their genetic pool condition [1]. There are about 30 subspecies identified in the $A$. mellifera species [2], which are also designated by the term «race», while in the Russian-language literature «the breed». Several breeds are propagated on the territory of the Russian Federation, namely Central Russian, Crain (or Carnik), Carpathian (some authors classify it as a subspecies of the Carnik of the $2^{\text {nd }}$ order), and Gray Mountain Caucasian breeds. The latter is considered as one of the best in terms of a range of economically beneficial traits (the longest proboscis, the highest efficiency and productivity, using of a wide species composition of honey plants, an extremely low propensity to swarm, peacefulness, etc.) [3]. The structure of the Gray Mountain Caucasian breed is inhomogeneous, and consists of populations, which significantly differ in their biological and economic characteristics [4]. Breeding, which is currently being conducted on the Krasnaya Polyana Experimental Station (the Greater Sochi district), is aimed at the preservation of the genetic pool and creation of new specialized lines with improved economic qualities $[5,6]$.

Determination of the bee breed and its allocation to one or another line is not an easy procedure, because the differences between the lines within the same species tend to be small. Furthermore, spontaneous hybridization is present. Evaluation is mostly based on appearance (morphometric criteria), physiological, etiologic features and indicators of economic value [2, 7]. Such measurements as the length of the proboscis, width of the third tergite and cubital index are mostly used [8]. It has been shown the possibility to differentiate between honeybee subspecies $A$. $m$. mellifera and $A$. m. carnica using morphometric methods [9]. However, an attempt of intraspecies differentiation of populations of the $A$. m. meda bees who live in different geographical regions (at a distance of $500 \mathrm{~km}$ ), which was based on morphometric data, was considered unsuccessful [10]. As the morphometric features depend on the geographic placement of the bees, their age, and food, and can vary widely, even within a single breed or population, there is a need to develop approaches that are based on an analysis of the genotype.

In recent years, molecular genetic methods, including investigation of allozymes [11], mitochondrial DNA [12-14], single nucleotide polymorphisms $[15,16]$ and microsatellites, become increasingly popular to differentiate the honeybee breeds, ecotypes and lines [17-20]. Evaluation of DNA markers is considered as a supplement to a conventional analysis based on morphometric criteria [21, 22]. Early papers, in which DNA analysis was used to identify honeybee intraspecies taxonomic units, relied on the determination of unique (private) alleles for the appropriate line [23]. Further on, applying Bayesian methods made possible genetic clustering of individuals (subspecies and smaller taxa) based on the genotype according to mulltiple unlinked loci [24]. The method is highly effective not only for determining the subspecies belonging to different evolutionary branches of $A$. mellifera $[25,26]$, but also for establishing the origin of closer taxa [27].

In the present paper, we have shown that the structure of the family tree built based on morphometric characters reflected neither the geographical affinity of the origin nor the similarity of the economically beneficial traits in the studied lines. Therefore, for their adequate characterization and differentiation, a combination of morphometric and molecular genetic methods is required. An integrated approach we used allows determining with high accuracy not only the 
breed of bees, but also smaller taxonomic groups. The obtained results can be used in activities aimed at restoring the purity of honeybee breeds.

The aim of this study was a comparative assessment of the diversity and differentiation of Apis mellifera caucasica lines based on morphometric analysis and microsatellites.

Technique. The investigations were carried out in 2014. Material for this study was the worker bees of Gray Mountain Caucasian breed of different lines, which were selected in five apiaries in the Greater Sochi district (Krasnodar krai). These were line № 19 (village of Medoveevka) (I), line № 13 (p.g.t. Krasnaya Polyana) (II), line № 12 (p.g.t. Krasnaya Polyana) (III), line № 49 (village of Kalinovoe Ozero) (IV) and line № 34 (village of Aibga) (V). For the analysis, five families with 22-30 bees in a family were selected in each line, a total of 25 families $(n=728)$, including $n=149$ for line $\mathrm{I}, n=147$ for line II, $n=147$ for line III, $n=137$ for line IV, and $n=148$ for line V. Bees were preserved in $96 \%$ ethanol and stored at $+4{ }^{\circ} \mathrm{C}$.

The length of the proboscis (LP, mm), the width of third tergite (W3T, $\mathrm{mm}$ ) were measured, and cubital index (CI) was calculated as the ratio between the larger and the smaller sides of the third cubital cell of the front wing [8].

DNA was isolated using the extraction with perchlorate [28], the biomaterial was the head of a worker bee. Seven microsatellite (MS) loci (A024, A88, A113, AP043, HB-C16-05, HB-THE-03, HB-C16-01) were amplified in one multiplex reaction using fluorescence-labelled primers. Reactions were performed in a final volume of $15 \mu \mathrm{l}$. The tubes were dispensed with $14 \mu \mathrm{l}$ of reaction mixture $(1 \mu \mathrm{l}$ consisting of $10 \times$ PCR buffer, $0.5 \mu \mathrm{l}$ of $2 \mathrm{mM}$ dNTPs solution, $0.7 \mu \mathrm{l}$ of $100 \mathrm{mM}$ DMSO solution, $4.6 \mu \mathrm{l}$ of $10 \mathrm{mM}$ mixture of primers, $0.1 \mu \mathrm{l}$ of Taq-polymerase, $7.1 \mu \mathrm{l}$ of double-distilled water) and added with $1 \mu \mathrm{l}$ (50$100 \mathrm{ng})$ of the studied genomic DNA. PCR buffer composition was $16.6 \mathrm{mM}$ $\left(\mathrm{NH}_{4}\right)_{2} \mathrm{SO}_{4}, 67.7 \mathrm{mM}$ Tris- $\mathrm{HCl}(\mathrm{pH}=8.8)$, and Tween $20(0.1$ of the final volume). The PCR was performed as follows: initial denaturation at $94{ }^{\circ} \mathrm{C}$ for $8 \mathrm{~min}$; annealing for 2 minutes at $55^{\circ} \mathrm{C}$; polymerization for $2 \mathrm{~min}$ at $72{ }^{\circ} \mathrm{C}$; 30 cycles of denaturation for $30 \mathrm{sec}$ at $94{ }^{\circ} \mathrm{C}$, annealing for $35 \mathrm{sec}$ at $55^{\circ} \mathrm{C}$, elongation for $40 \mathrm{sec}$ at $72{ }^{\circ} \mathrm{C}$; and elongation for $20 \mathrm{~min}$ at $72{ }^{\circ} \mathrm{C}$. Separation of the PCR products was performed on a genetic analyzer ABI3130xl (Applied Biosystems, USA) using the ROX standard. Electrophoretograms were processed using the software GeneScan v. 3.7 and Genotyper v. 3.7 (Applied Biosystems, USA).

Interfamily variability by morphometric characters was assessed using two-factor nested analysis of variance and the software Statistica v. 6 [29]. The belonging to the family and the line (hierarchical subordinated factor) was used as fixed effects. $\mathbf{M}_{\mathrm{st}}$ was calculated as follows:

$$
\mathrm{M}_{\mathrm{st}}=\frac{\mathrm{F}-1}{\mathrm{~F}-1+n^{*}}
$$

where $\mathrm{F}$ was dispersion ratio, $n^{*}$ was mean geometric volume of samples. $\mathrm{M}_{\mathrm{st}}$ may take values ranged from 0 to 1 , and be a measure of morphological differentiation between separate populations, and, in fact, it is an analogue of $F_{\text {st }}[30]$.

Genetic differences between the families of the honeybee according to MS were assessed using the $F_{\text {st }}$ value [31] for pairwise comparison and based on genetic distances by M. Nei [32]. The pairwise matrices obtained were used for constructing the distribution of family centrodes in the space of the first two principal coordinates (PCA, principal component analysis). To quantify the interfamily variability within the lines, $F_{\text {st }}$ and $R_{\text {st }}$ (AMOVA) values were calculated [33] using the software GenAlEx v. 6.5 [34].

The differentiation level of the five studied lines of $A . m$. caucasica was evaluated based on morphometric characters by calculating the Euclidean dis- 
tances. The values obtained were used to construct a dendrogram of similarity using single linkage method (single linkage) in an algorithm of hierarchical clustering [29]. Assessment of the line differentiation by MSs was carried out based on calculating the values of genetic distances according to M. Nei [32]. A similarity dendrogram was constructed by UPGMA and the software PAST (v. 3.03). The dendrogram was tested for cluster topology robustness by performing 999 permutations using a bootstrap method.

Results. When forming, each bee line was strictly aimed at obtaining material with prespecified economically beneficial traits. The bee queen from line III have high egg production ability in a period of preparation for the main nectar flow, and families have increased productivity for honey. Lines IV and V are characterized by the early development when compared to lines I, II and III. Bees in line IV are less winter-hardy, while line II stands out with elevated, and line I with high winter hardiness.

There were significant differences found between the lines for two of the three assessed traits, i.e. the length of proboscis and the width of the third tergite, whereas we found no differences in the values of cubital index between the lines (Table 1). Bees in line II had their LP value 0.05-0.07 mm smaller $(\mathrm{p}<0.001)$ and W3T 0.04-0.11 mm larger $(\mathrm{p}<0.001)$ when compared to other studied lines. The maximum length of the proboscis was seen in bees line III. In lines III and IV, the W3T value was $0.08-0.11 \mathrm{~mm}$ smaller than in other studied lines $(\mathrm{p}<0.001)$. These findings may be the result of different strategies used in the stock breeding of these lines.

1. The morphometric characters in honeybee (Apis mellifera caucasica L.) various lines of Gray Mountain Caucasian breed ( $X \pm X$, Krasnodar krai, 2014)

\begin{tabular}{|c|c|c|c|}
\hline \multirow{2}{*}{ Line } & \multicolumn{3}{|c|}{ Morphometric character } \\
\hline & $\mathrm{LP}, \mathrm{mm}$ & W3T, mm & CI \\
\hline I & $6.88 \pm 0.006^{a, b, c, d}$ & $4.72 \pm 0.010^{\mathrm{a}, \mathrm{b}, \mathrm{c}, \mathrm{d}}$ & $0.502 \pm 0.008$ \\
\hline II & $6.94 \pm 0.005^{\mathrm{b}}$ & $4.67 \pm 0.010^{\mathrm{b}, \mathrm{e}, \mathrm{f}}$ & $0.509 \pm 0.007$ \\
\hline III & $6.95 \pm 0.004 \mathrm{c}, \mathrm{i}$ & $4.64 \pm 0.008^{c, f, g}$ & $0.513 \pm 0.007$ \\
\hline IV & $6.94 \pm 0.004 \mathrm{~d}, \mathrm{i}$ & $4.61 \pm 0.009^{d}, e, h$ & $0.515 \pm 0.008$ \\
\hline V & $6.93 \pm 0.005^{\mathrm{a}}$ & $4.68 \pm 0.010^{\mathrm{a}, \mathrm{g}, \mathrm{h}}$ & $0.524 \pm 0.008$ \\
\hline
\end{tabular}

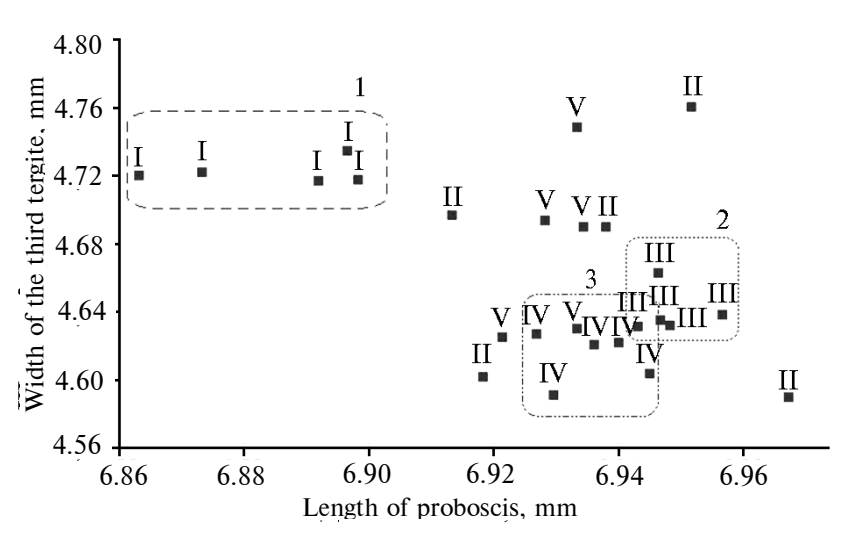

Fig. 1. Distribution of 25 honeybee (Apis mellifera caucasica L.) families of the Gray Mountain Caucasian breed in two-dimensional space for the length of proboscis and the width of the third tergite: I-V - the lines of honeybee under examination; 1 3 - clusters being formed (Krasnodar krai, 2014). Description of lines is given in the Technique section.
The data of twofactor nested analysis of variance supported the presence of significant differences for LP and W3T values both between lines and between families within each of the lines.

The formation of clusters based on the linear principle was observed for three of the five lines examined (Fig. 1). Only families in line I were distributed within one separate 1st cluster, but they were characterized by the highest variability for LP 
$\left(C v_{\mathrm{LP}}=1.11 \%\right)$ compared to other lines $\left(C v_{\mathrm{LP}}=0.69-0.86 \%\right)$, with an average heterogeneity for W3T $\left(C v_{\mathrm{W} 3 \mathrm{~T}}=2.49 \%\right)$. Families in lines III and IV formed two consolidated clusters $\left(C V_{\mathrm{LP}} 0.74 \%\right.$ and $0.69 \%$ and $C V_{\mathrm{W} 3 \mathrm{~T}} 2.15 \%$ and $2.33 \%$, respectively), which partially overlap one another. In bees from lines II and V, both characters greatly varied $\left(C V_{\mathrm{LP}} 0.79 \%\right.$ and $0.86 \%, C v_{\mathrm{W} 3 \mathrm{~T}} 2.66 \%$ and $2.52 \%$, respectively). Significant differences $(\mathrm{p}<0.05)$ between the families within the lines were observed for LP in line II $\left(\mathrm{M}_{\mathrm{st}}=0.1359\right)$ and W3T in lines II $\left(\mathrm{M}_{\mathrm{st}}=0.2869\right)$ and $\mathrm{V}\left(\mathrm{M}_{\mathrm{st}}=0.1525\right)$. Interline differences were significant $(\mathrm{p}<0.05)$ for the LP $\left(\mathrm{M}_{\mathrm{st}}=0.1453\right)$ and W3T $\left(\mathrm{M}_{\mathrm{st}}=0.1097\right)$, while we found no significant differences for CI.

In general, a great heterogeneity should be noted based on studied parameters in bees from lines II and V, and, on the contrary, a greater consolidation among bees in lines III and IV. Bees in line I showed significant differences compared to others on both parameters, however, they were characterized by significant interfamily differences in the LP values.

Analysis of the MS profiles revealed similar trends in determining intraand interfamily variability (Table 2).

2. Iintra- and interfamily (within lines) genetic variance in the honeybees (Apis mellifera caucasica L.) of Gray Mountain Caucasian breed by seven microsatellite loci (Krasnodar krai, 2014)

\begin{tabular}{|c|c|c|c|c|}
\hline \multirow{2}{*}{ Line } & \multicolumn{4}{|c|}{ Intra- and interfamily variance } \\
\hline & $F_{\text {is }}$ & $F_{i t}$ & $\mathrm{~F}_{\mathrm{st}}($ freq $)$ & $\mathrm{R}_{\mathrm{st}}$ (AMOVA) \\
\hline I & -0.048 & 0.052 & 0.124 & 0.405 \\
\hline II & 0.128 & 0.189 & 0.104 & 0.300 \\
\hline III & 0.090 & 0.162 & 0.096 & 0.266 \\
\hline IV & 0.062 & 0.143 & 0.095 & 0.141 \\
\hline V & 0.077 & 0.169 & 0.102 & 0.462 \\
\hline $\mathrm{I}-\mathrm{V}$ & 0.132 & 0.162 & 0.040 & 0.094 \\
\hline
\end{tabular}
(I-V) using a line as a subpopulation. Description of lines and microsatellite loci is given in the Methods section.

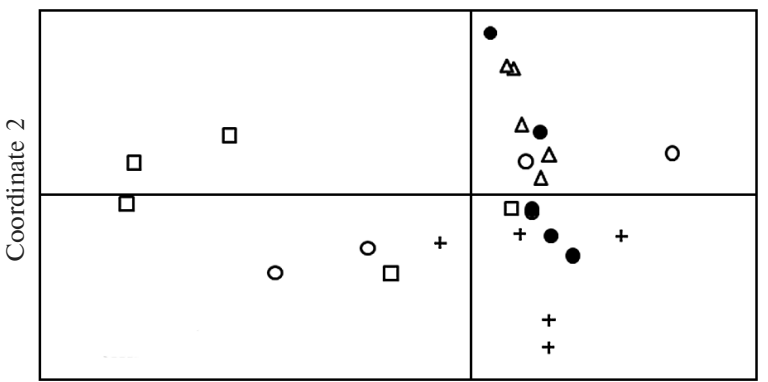

Coordinate 1

Fig. 2. Distribution of centrodes for the honeybee (Apis mellifera caucasica L.) families of Gray Mountain Caucasian breed in the space of the first two principal coordinates calculated based on the $F_{\text {st }}$ matrix in pairwise comparison for seven microsatellite loci: $\circ-$ line I, $\square-$ line II, +- line III, $\Delta-$ line IV, • - line V (Krasnodar krai, 2014). Description of lines is given in the Technique section. Calculations were carried out for the whole sample using a family as a subpopulation (number of subpopulations is 25).

We observed an excess of heterozygotes in line I (the only one among the studied lines) (a negative value of $F_{\text {is }}$ ), which can be considered as an indication of the high heterogeneity. Bees of this line were characterized by the minimum individual variability relative to the whole sample (the value of $F_{\text {it }}$ was 2.75-3.63 times lower in comparison with the lines II-V) and the maximum interfamily variation. Lines II-V were characterized by a deficiency of heterozygotes (positive values of the $F_{\text {is }}$ indicator), a relatively higher individual variability relative to the whole sample and lower values of interfamily variability comparing to line I. The lowest interfamily differences assessed by $F_{\text {st }}$ and $R_{\text {st }}$ (AMOVA) were observed in lines III and IV.

Results of the PCA analysis revealed the greatest similarity of the families within line IV, while lines I and II were characterized by the largest interfamily 
differences (Fig. 2).

Analysis of the differentiation of the studied lines for three morphometric characteristics and seven MS loci revealed differences in the structure of the family tree (Fig. 3). A dendrogram based on MS data is a reflection of the geographical distance of the studied lines (Fig. 3, A). The formation of the two main clusters may have been a result of the geographic isolation of lines I, II and III located in the vicinity of Krasnaya Polyana (the first apiary is located on the southern slope of the ridge Achi-Shkho with altitude of 2,391 m, the second and third ones are located in the gorge of the river Mzymta) from line IV (the apiary is located at a distance of $15-25 \mathrm{~km}$ from the three listed ones and separated from them by the Alec ridge with altitude of $1,000 \mathrm{~m}$ ) and line $\mathrm{V}$ (located in the upper reaches of the Psou river, removed from the first, second and third apiaries at a distance of $10-16 \mathrm{~km}$ and separated from them by the ridge Aibga 2,460 m high). Significant genetic differences between lines IV and V could be due to their geographic isolation. Apiaries these lines are bred in are located at a distance of about $30 \mathrm{~km}$ from each other and are separated by the Alec ridge, which stretches for $20 \mathrm{~km}$ between the rivers Mzymta and Sochi, $15 \mathrm{~km}$ from the Black Sea coast, and the Aibga ridge, stretching from the northwest to the south-east for $23 \mathrm{~km}$ and separating the middle part of the Mzymta river valley from the Psou river head.

A

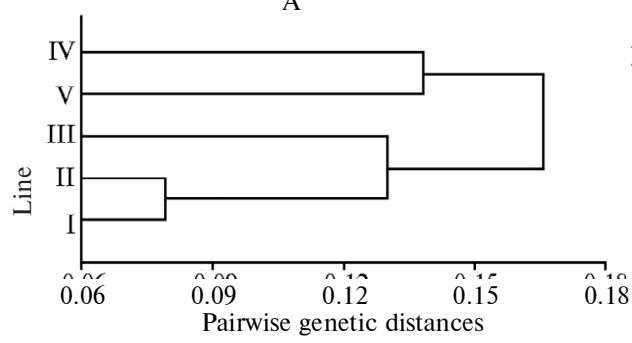

B

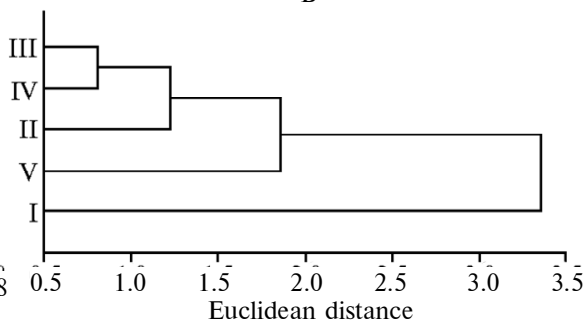

Fig. 3. Dendrogram of similarity for five lines of honeybee (Apis mellifera caucasica L.) Gray Mountain Caucasian breed calculated for seven microsatellite loci (A) and three morphometric characteristics (B) (Krasnodar krai, 2014). The pairwise genetic distances were calculated according to M. Nei [32]. A clustering method of UPGMA was applied in both cases. Description of lines is given in the Technique section.

The structure of the family tree based on morphometric characters does not reflect the geographic closeness (differences) of the origin, or similarities (differences) in the economically useful traits of studied lines.

Thus, the results of our study of the morphometric parameters and microsatellites show similar trends when assessing intra- and interline (between families) variation. However, there were differences in differentiation and the pattern of genealogical relations between the lines when assessed using two methods. It is possible that these differences are due to the fact that most of the differences in the conventional morphometric traits (morphological measurements) stay within the seasonal variations, and are of little use for the identification of the local populations. In addition, they are more prone to the pressure of environmental factors not associated with exposure to artificial directional selection. Microsatellites are mostly selection neutral, and reflect more distant evolutionary events. Therefore, to obtain the most complete information on the population status and dynamics, it is required to consider the results obtained with both methods.

\section{REFEREN C ES}

1. B r a nd o rf A.Z. Pchelovodstvo, 2012, 7: 14-16. 
2. Rut n e r F. Biogeography and taxonomy of honey bees. Germany, Berlin, Springer, 1988.

3. B ilas h G.D., K rivts ov N.I. Pchelovodstvo, 1984, 2: 12-13.

4. Alp a tov V.V. Porody medonosnoi pchely [Breeds of honey bees]. Moscow, 1948.

5. Sokol'ski i S.S. Materialy Mezhdunarodnoi nauchnoi konferentsii «Sovremennye napravlenii nauchno-tekhnicheskogo progressa v pchelovodstve» [Proc. Int. Conf. «Recent progress in honeybee rearing»]. Rybnoe, 2007: 80-82.

6. Sok ol'ski i S.S., S a v u s h k i n a L.H. Pchelovodstvo, 2006, 2: 17-18.

7. Ruttner F., Tassencourt L., Louve aux J. Biometrical-statistical analysis of the geographic variability of Apis mellifera L. Apidologie, 1978, 9: 363-381 (doi: 10.1051/apido:19780408).

8. Ru t t n e r F. Tekhnika razvedeniya i selektsionnyi otbor pchel [Breeding and selection of honeybees]. Moscow, 2006.

9. Oleksa A., Tofilski A. Wing geometric morphometrics and microsatellite analysis provide similar discrimination of honey bee subspecies. Apidologie, 2015, 46: 49-60 (doi: 10.1007/s13592-014-0300-7).

10. Rahimi A., Mirmoayedi A., Kahrizi D., Abdolshahi R., Kazemi E., Ya ri K. Microsatellite genetic diversity of Apis mellifera meda skorikov. Mol. Biol. Rep., 2014, 41(12): 7755-7761 (doi: 10.1007/s11033-014-3667-7).

11. Ivanova E., B i enkowska M., Panasiuk B., Wilde J., Staykova T., Stoya nov I. Allozyme variability in populations of $A$. mellifera mellifera (Linnaeus 1758.), A. $\mathrm{m}$. carnica (Pollman, 1879) and A. m. caucasica (Gorbachev, 1916) from Poland. Acta Zool. Bulg. Suppl., 2012, 4: 81-88.

12. Kalashnikov A.E., M a s lennikov I.V., Kolbina L.M., U dina I.G. Sel'skokhozyaistvennaya biologiya [Agricultural Biology], 2013, 4: 88-92 (doi: 10.15389/agrobiology.2013.4.88rus, doi: 10.15389/agrobiology.2013.4.88eng).

13. I ly a s ov R.A., Kutu e v I.A., P e tukhov A.V., Poskryakov A.V., N i kole nko A.G. Phylogenetic relationships of dark European honeybees Apis mellifera mellifera L. from the Russian Ural and West European populations. J. Apic. Sci., 2011, 55: 67-76.

14. Gruber K., Schцning C., Ot te M., Kinuthia W., Has se $1 \mathrm{mann}$ M. Distinct subspecies or phenotypic plasticity? Genetic and morphological differentiation of mountain honey bees in East Africa. Ecol. Evol., 2013, 3(10): 3204-3218 (doi: 10.1002/ece3.711).

15. Whitfield C.W., B ehura S.K., B erlocher S.H., Clark A.G., Johnston J.S., Sheppard W.S., S mith D.R., Suarez A.V., We aver D., Tsutsui N.D. Thrice out of Africa: Ancient and recent expansions of the honey bee Apis mellifera. Science, 2006, 314: 642-645 (doi: 10.1126/science.1132772).

16. Harpur B.A., Kenta C.F., Molodtsova D., Lebonb J.M.D., Alqarnic A.S., $\mathrm{O}$ w a y s s c A.A., $\mathrm{Z}$ a y e d A. Population genomics of the honey bee reveals strong signatures of positive selection on worker traits. PNAS USA, 2013, 111(7): 2614-2619 (doi: 10.1073/pnas.1315506111).

17. J e n se n A.B., Palme r K.A., B o o ms ma J.J., Pedersen B.V. Varying degrees of Apis mellifera ligustica introgression in protected populations of the black honeybee, Apis mellifera mellifera, in northwest Europe. Mol. Ecol., 2005, 14: 93-106 (doi: 10.1111/j.1365294X.2004.02399.x).

18. B odur C., Kence M., Kence A. Genetic structure of honeybee, Apis mellifera L. (Hymenoptera: Apidae) populations of Turkey inferred from microsatellite analysis. J. Apic. Res., 2007, 46: 50-56.

19. Krivtsov N.I., Gory a cheva I.I., Udina I.G., B orodachev A.V., Mo nakhov a M.A. Sel'skokhozyaistvennaya biologiya [Agricultural Biology], 2010, 6: 26-29.

20. Zinov'eva N.A., Krivtsov N.I., Fornara M.S., Gladyr' E.A., Borodachev A.V., L e b e d e v V.I. Sel'skokhozyaistvennaya biologiya [Agricultural Biology], 2011, 6: 75-79.

21. Krivtsov N.I., Gladyr' E.A., Volkova V.V., Fornara M.S., Lebe d e v V.I., Z i no v' e v a N.A. Problemy biologii produktivnykh zhivotnykh, 2011, 1: 41-45.

22. Ostroverkhova N.V., Konusova O.L., Kucher A.N., Pogorelov Yu.L., Be ly k h E.A., Vorotov A.A. Biologiya, 2013, 1(21): 161-172.

23. Garnery L., Franck P., Baudry E., Vautrin D., Cornuet J.M., Solig $\mathrm{n}$ a c M. Genetic diversity of the west European honey bee (Apis mellifera mellifera and A. m. iberica). II. Microsatellite loci. Genet. Sel. Evol., 1998, 30: 49-74 (doi: 10.1186/12979686-30-S1-S49).

24. Pritchard J.K., Stephens M., D o n nelly P. Inference of population structure using multilocus genotype data. Genetics, 2000, 155: 945-959.

25. Oleks a A., Chybi cki I.J., T ofi lski A., B u rczyk J. Nuclear and mitochondrial patterns of introgression into native dark bees (Apis mellifera mellifera) in Poland. J. Apic. Res., 2011, 50: 116-129 (doi: 10.3896/IBRA.1.50.2.03).

26. Alburaki M., Bertrand B., Legout H., Moulin S., Alburaki A., Sheppard W.S., Garnery L. A fifth major genetic group among honeybees revealed in Syria. 
BMC Genetics, 2013, 14: 117 (doi: 10.1186/1471-2156-14-117).

27. Muñoz I., Da 11' Olio R., Lodesani M., De La Rúa P. Population genetic structure of coastal Croatian honeybees (Apis mellifera carnica). Apidologie, 2009, 40: 617-626 (doi: 10.1051/apido/2009041).

28. Zinov'eva N.A., Popov A.N., Ernst L.K., Marzanov N.S., Bochkarev V.V., Stre k o zov N.I., B re m G. Metodicheskie rekomendatsii po ispol'zovaniyu metoda polimeraznoi tsepnoi reaktsii $v$ zhivotnovodstve [Manual of PCR analysis technique in animal husbandry]. Dubrovitsy, 1998.

29. K h a 1 a f y a $\mathrm{n}$ A.A. STATISTICA 6. Statisticheskii analiz dannykh [STATISTICA 6. Statistical analysis]. Moscow, 2007.

30. K r a m a re n k o S.S. Vestnik zoologii, 2009, 43(1): 51-58.

31. We i r B.S., Cocke $\mathrm{rham}$ C.C. Estimating F-statistics for the analysis of population structure. Evolution, 1984, 38: 1358-1370 (doi: 10.2307/2408641).

32. N e i M., K o e h n R. Genetic polymorphism and the role of mutation in evolution. In: Evolution Genes and Proteins. Sinauer, Sunderland, MA, 1983: 165-190.

33. S latk i n M. A measure of population subdivision based on microsatellite allele frequencies. Genetics, 1995, 139: 457-462.

34. Peakall R., S mouse P.E. GenAlEx 6.5: genetic analysis in Excel: population genetic software for teaching and research - an update. Bioinformatics, 2012, 28: 2537-2539 (doi: 10.1093/bioinformatics/bts460). 